\title{
SHELTER FROM THE STORM: $A$ COMMENT ON SURESH V. CANADA (MINISTER OF CITIZENSHIP AND IMMIGRATION)
}

\section{Peter J. CARVER ${ }^{\circ}$}

\section{INTRODUCTION}

When the Supreme Court of Canada reserves judgment at the close of argument, it generally does so confident in the assumption that the legal world will stay in place pending its decision. On 22 May 2001, the Court reserved judgment in Suresh v. Canada (Minister of Citizenship and Immigration), ' a case concerning the Canadian government's authority to deport suspected terrorists to countries where they face a substantial risk of torture. In the seven months that passed before the Court rendered judgment on 11 January 2002, terrorists had attacked and destroyed the World Trade Center in New York, and Parliament had enacted both an extensive legislative package directed at the threat of terrorism, and a fully rewritten immigration statute. The world, everyone said, would never be the same. That certainly seemed true of the Canadian legal world dealing with terrorism and immigration.

In this new atmosphere, would the Court be willing to further develop the jurisprudence, founded with its landmark decision in Singh v. Canada (Minister of Employment and Immigration) ${ }^{2}$ that extends the protection of the Canadian Charter of Rights and Freedoms ${ }^{3}$ to persons at risk of serious harm if deported from Canada? The Court's unanimous decision in Suresh provides a qualified Yes.

This outcome is noteworthy in its own right. It is also deceptively simple. The Court's reasons for judgment represent an intricate weave of several important constitutional and administrative law issues. This comment seeks to explore these issues through the lens of a single theme: the nature of discretionary decision-making, particularly ministerial discretion. It does so by looking at four aspects of discretion inspired by the Court's discussion in Suresh:

(1) The Court's interpretation of the statutory terms "terrorism" and "danger to the security of Canada," especially in light of the events of 11 September 2001. Suresh had alleged that the terms were unconstitutionally vague. This allegation embodies a concern many have about anti-terrorism enforcement measures: that

Assistant Professor, Faculty of Law, University of Alberta. The author wishes to thank Professor June Ross for her helpful comments.

(2002), 208 D.L.R. (4th) 1, [2002] S.C.J. No. 3, online: QL (SCJ) [hereinafter Suresh cited to S.C.J.].

2 [1985] 1 S.C.R. 177. In actuality, only three of six Justices participating in Singh found for the appellant on constitutional grounds, in an opinion written by Wilson J. Beetz J. wrote the other judgment, which found for the appellant under the Canadian Bill of Rights, S.C. 1960, c. 44, reprinted in R.S.C. 1985, App. III.

3 Part I of the Constitution Act, 1982, being Schedule B to the Canada Act 1982 (U.K.), 1982, c. 11 [hereinafter Charter]. 
the scope of the word "terrorism" is itself a form of discretion, or potential arbitrariness, in the hands of enforcement authorities.

(2) Developments in Suresh related to administrative law principles of substantive review of discretion. Much of the recent development of these principles has occurred in immigration cases, including Baker v. Canada (Minister of Citizenship and Immigration). ${ }^{4}$ In Suresh, the Supreme Court backed away from a position it had taken in Baker.

(3) Constitutional issues involved in the application of s. 7 of the Charter to the Minister's exercise of discretion to deport Suresh. Significantly, the Court located the constitutional problem in Suresh in the exercise of discretion, rather than in the statutory provision granting the discretion.

(4) Possible implications of Suresh for the constitutionality of a provision in the new Immigration and Refugee Protection $\mathrm{Act}^{5}$ that eliminates discretionary relief for permanent residents faced with deportation on certain grounds.

The latter point arises because at the same time the Supreme Court showed in Suresh that it would not shy away from extending constitutional protection to suspected terrorists in the post-11 September period, Parliament moved to restrict a long-standing appeal recourse for permanent residents. This discussion brings into consideration a second judgment released by the Court on the same day as Suresh, Chieu v. Canada (Minister of Citizenship and Immigration). ${ }^{6}$

\section{Summary of FactS and Decision In SURESH}

\section{A. FACTS}

Manickavasagam Suresh arrived in Canada in 1990 from Sri Lanka and claimed refugee status based on his purported fear of persecution by the Liberation Tigers of Tamil Eilam (LTTE) - the rebel group fighting for Tamil independence in Sri Lanka's brutal civil war - and the Sri Lanka government's inability to protect him. Suresh was successful in this claim before the Convention Refugee Determination Division of the Immigration and Refugee Board (IRB) in 1991. Before he could obtain permanent resident status, Canadian authorities came to believe that, contrary to the story he had told in seeking refugee status, Suresh was in fact a leading figure in the LTTE, and was actively fundraising for the organization in Canada. The federal government commenced deportation proceedings against Suresh in early 1995.

[1999] 2 S.C.R. 817 [hereinafter Baker].

S.C. 2001 , c. 27 [hereinafter IRPA]. IRPA was proclaimed on 28 June 2002 (SI/2002-97), except for ss. 171 and 194-95, which deal with the new Refugee Appeal Division.

(2002), 208 D.L.R. (4th) 107, [2002] S.C.J. No. 1, online: QL (SCJ) [hereinafter Chieu cited to S.C.J.]. The Court delivered judgment in four immigration cases on 11 January 2002, in two pairs of companion cases. The companion case to Suresh is Ahani v. Canada (Minister of Citizenship and Immigration) (2002), 208 D.L.R. (4th) 57, [2002] S.C.J. No. 4, online: QL (SCJ) [hereinafter Ahani]. The companion case to Chieu is Al Sagban v. Canada (Minister of Citizenship and Immigration) (2002), 208 D.L.R. (4th) 148, [2002] S.C.J. No. 2, online: QL (SCJ) [hereinafter $A l$ Sagban]. 
The government sought to deport Suresh through the "security certificate" process set out in s. 40.1 of the Immigration Act. $^{7}$ The process has three principal consequences: (a) on issuance, the person concerned is subject to automatic arrest and detention; (b) if upheld as reasonable, the person has no right of appeal to the Immigration Appeal Division (IAD) of the Immigration and Refugee Board (IRB); ${ }^{8}$ (c) intelligence information can be shielded from disclosure to the person and counsel.

The process commences with a joint issuance of a certificate stating that, based on intelligence information, a person is inadmissible on one or more "security grounds" by the Minister of Immigration and the Solicitor General. The certificate in Suresh's case stated that he was believed to be a member of an organization, the LTTE, that is or was engaged in terrorism. ${ }^{9}$ A certificate is subject to automatic review by a justice of the Federal Court Trial Division, who has the authority to decide how much intelligence information to disclose to the individual and his or her counsel, and then to conduct a hearing with their participation on whether the certificate is reasonable. In Suresh's case, a fifty-day hearing took place before Teitelbaum J., who concluded that the certificate was reasonable. He found that the LTTE had engaged in terrorism in Sri Lanka, that Suresh lacked credibility and had lied in his refugee claim, and further that Suresh was an executive member of LTTE, engaged in fundraising activities in Canada. He did not find that Suresh himself had engaged in terrorist activities. On this basis, Suresh was found to be deportable, or "inadmissible" 10 to Canada, as being a member of an organization that engaged in terrorism.

The one right that the United Nations Convention Relating to the Status of Refugees guarantees to refugees is the right of "non-refoulement" - a right not to be returned

Immigration Act, R.S.C. 1985, c. [-2 [hereinafter Immigration Act].

lbid., s. 70(3.1).

Pursuant to ss. 19(1)(e)(iv)(C) and 19(1)(f)(B) of the Immigration Act:

19 (1) No person shall be granted admission who is a member of any of the following classes ...

(e) persons who there are reasonable grounds to believe

(iv) are members of an organization that there are reasonable grounds to believe will, ...

(C) engage in terrorism;

(f) persons who there are reasonable grounds to believe ...

(iii) are or were members of an organization that there are reasonable grounds to believe is or was engaged in ...

(B) terrorism,

except persons who have satisfied the Minister that their admission would not be detrimental to the national interest.

The word "terrorism" is not otherwise defined in the Immigration Act. It is also to be noted that a determination turns on a double finding of "reasonable grounds to believe": first, that the person is or was a member of the organization in question; second, that the organization is, was, or will be engaged in terrorism.

11 The new legislation has simplified terminology in this area. Whereas the Immigration Act referred separately to grounds of "inadmissibility" and grounds of "removal" (located in ss. 19 and 27 respectively), the IRPA refers to grounds of "inadmissibility" for both functions. This paper will use the term in the latter sense - i.e., "inadmissible" means "removable" or "deportable." 
to the country where they faced persecution. The right is subject to an exception set out in article 33(2) of the Convention:

The benefit of the present provision may not, however, be claimed by a refugee whom there are reasonable grounds for regarding as a danger to the security of the country in which he is, or who, having been convicted by a final judgment of a particularly serious crime, constitutes a danger to the community of that country. ${ }^{11}$

The Immigration Act incorporates the principle of non-refoulement, and the national security exception, in s. 53(1)(b):

Notwithstanding subsections 52(2) and (3), no person who is determined under this Act or the regulations to be a Convention refugee, nor any person who has been determined to be not eligible to have a claim to be a Convention refugee determined by the Refugee Division on the basis that the person is a person described in paragraph $46.01(1)$ (a), shall be removed from Canada to a country where the person's life or freedom would be threatened for reasons of race, religion, nationality, membership in a particular social group or political opinion unless ...

the person is a member of an inadmissible class described in paragraph 19(1)(e), ( $)$,

$(g),(j),(k)$ or $(l)$ and the Minister is of the opinion that the

person constitutes a danger to the security of Canada. ${ }^{12}$

To deport Suresh, the Minister was required to formulate the opinion that Suresh constituted a danger to the security of Canada. The Minister followed existing policy in this regard. Suresh was asked to make a submission in writing. As part of his submission, Suresh claimed that he would likely be tortured if returned to Sri Lanka. The submission was reviewed by Immigration Officer Donald Gautier, who made a report and recommendation to the Minister. Gautier's report acknowledged that Suresh faced a risk of torture in Sri Lanka, but added that the risk was mitigated by the

Convention Relating to the Status of Refugees, 2 September 1969, Can. T.S. 1969 No. 6 [hereinafter Refugee Convention].

Immigration Act, supra note 7 [emphasis added]. The corresponding provision in the IRPA reads:

115. (1) A protected person or a person who is recognized as a Convention refugee by another country to which the person may be returned shall not be removed from Canada to a country where they would be at risk of persecution for reasons of race, religion, nationality, membership in a particular social group or political opinion or at risk of torture or cruel and unusual treatment or punishment.

(2) Subsection (1) does not apply in the case of a person

(a) who is inadmissible on grounds of serious criminality and who constitutes, in the opinion of the Minister, a danger to the public in Canada; or

(b) who is inadmissible on grounds of security, violating human or international rights or organized criminality if, in the opinion of the Minister, the person should not be allowed to remain in Canada on the basis of the nature and severity of acts committed or of danger to the security of Canada.

This provision is different from s. 53(1)(b) of the Immigration Act in a number of ways. Although the non-refoulement provision makes specific mention of not deporting a refugee to a risk of torture or cruel or unusual punishment, this remains subject to exceptions for national security, and the severity of the acts committed. Section 115 thus contemplates the same decision-making exercise as is found in s. 53(1)(b). 
protection likely afforded him by his high profile. In any event, Gautier wrote, any such risk was outweighed by the seriousness of Suresh's activities in support of LTTE to Canada. The Minister acted on this recommendation by issuing a danger-to-security opinion on 6 January 1998 without giving reasons.

\section{B. THE SUPREME COURT'S DECISION IN SURESH}

Suresh commenced an application for judicial review, raising a host of constitutional and administrative law issues. ${ }^{13}$ The principal constitutional issue dealt with whether s. 53(1)(b) violates s. 7 of the Charter by permitting refoulement of a refugee to torture. Section 7 reads:

Everyone has the right to life, liberty and security of the person and the right not to be deprived thereof except in accordance with the principles of fundamental justice.

The Supreme Court rejected the challenge to the statute. ${ }^{14}$ It viewed s. $53(1)(\mathrm{b})$ as granting a discretionary authority to the Minister with respect to deporting refugees. The Court said that when a risk of torture exists, the Minister is bound by s. 7 and must act in accordance with principles of fundamental justice.

The Court found that Suresh's procedural rights had been violated. Specifically, the Court found that Suresh should have received a copy of Officer Gautier's report and been given a chance to respond to it before the Minister made her decision. Further, the Minister should have provided reasons for her decision. The Court did not agree with Suresh that he was entitled to an oral hearing. Given the breach of due process, the Court remitted the s. 53(1)(b) decision to the Minister for reconsideration, following appropriate disclosure and submissions.

The Court also engaged in an extensive obiter discussion of substantive fundamental justice as it applies to the Minister's discretion, expressly for the purpose of giving guidance for the future. The Court said that s. 7 calls for a balancing of the factors which go to the state's interest in deporting security risks against factors which go to the individual's interest in being protected from torture. Many of these factors will be

The Court summarized the issues raised by Suresh at para. 2:

The appeal requires us to consider a number of issues: the standard to be applied in reviewing a ministerial decision to deport; whether the Charter precludes deportation to a country where the refugee faces torture or death; whether deportation on the basis of mere membership in an alleged terrorist organization unjustifiably infringes the Charter rights of free expression and free association; whether "terrorism" and "danger to the security of Canada" are unconstitutionally vague; and whether the deportation scheme contains adequate procedural safeguards to ensure that refugees are not expelled to a risk of torture or death. all decided against Suresh. The questions all involve Charter challenges to statutory provisions. In addition to the s. 7 challenge to s. $53(1)(b)$ of the Immigration Act, they include challenges to the inadmissibility ground of "membership" in a terrorist organization based on freedom of expression and freedom of association in ss. 2(b) and 2(d) of the Charter, respectively, and challenges to the statutory phrases "danger to the security of Canada" and "terrorism" for vagueness. 
constant from case to case, including international law norms against torture and deporting persons to torture. ${ }^{15}$ Other factors will be case-specific. The balancing of the constant factors led the Court to identify what is in essence a "constitutional standard" for the Minister in deciding whether to order deportation where the person faces a substantial risk of torture: the Minister may decide to deport only in "exceptional circumstances." The Court did not specify the nature of such circumstances.

The Court engaged in a bifurcation of issues before the Minister, dividing them between factual issues and a residual discretionary decision. The factual issues are: (a) whether the refugee is a "danger to the security of Canada," the issue expressly posed by s. 53(1)(b); and (b) whether the refugee faces a "substantial risk of torture" in the receiving country. The Minister's answers to these questions are subject to judicial review in the usual administrative law sense. The appropriate standard of review is the highest level of deference: only if it finds them patently unreasonable can a reviewing court quash the Minister's findings of fact on security and on risk of torture. The residual discretionary decision is whether, if (a) and (b) are both answered affirmatively, the refugee should be deported. This is governed by the "constitutional standard."

A summary of this rather complicated framework for ministerial decision-making shows the following conceptual stages:

(1) to order refoulement of a refugee, the Minister must form the opinion that he or she constitutes a "danger to the security of Canada"; this is a factual determination to which a court in judicial review will accord deference;

(2) if the refugee raises a prima facie case that he or she faces a substantial risk of torture in the receiving country, then s. 7 of the Charter requires that the Minister's decision to deport be made, procedurally and substantively, in accordance with the principles of fundamental justice;

(3) substantive justice requires that if the prima facie case is made out, the Minister must decide whether the refugee faces a substantial risk of torture; this is a factual determination to which a reviewing court will accord deference;

(4) should a substantial risk of torture exist, s. 7 requires as a matter of substantive justice that the Minister not deport the refugee, barring "exceptional circumstances."

A principal source of international norms is the Convention Against Torture and Other Cruel, Inhuman or Degrading Treatment or Punishment, 24 July 1987, Can. T.S. 1987 No. 36 [hereinafter CAT]. The Supreme Court starts its discussion of $C A T$ by stating, "[i]nternational treaty norms are not, strictly speaking, binding in Canada unless they have been incorporated into Canadian law by enactment" (Suresh, supra note 1 at para. 60). Nevertheless, the Court engages in a lengthy analysis of the prohibition in Article 3 of $C A T$ against refoulement to torture "where there are substantial grounds for believing" that torture will occur. The Court concludes that this is a non-derogable norm of international law. See Suresh, supra note 1 at paras. 59-75.

Although the international law norm appears to be a significant factor in the Court's thinking in Suresh, the Court deciines to find that deportation to a substantial risk of torture is per se unconstitutional, ruling that it is permissible in exceptional circumstances. 


\section{COMment}

The Supreme Court's decision in Suresh is admirable. A mere four months following the events of 11 September, the Justices were prepared to say that a suspected terrorist is entitled to considerable protection under Canadian law. The Court upheld the centrality of basic human rights principles in the midst of a torrent of concern about safety and security in a newly dangerous world. At the same time, the Court did not state this commitment in categorical terms. It declined to give narrow definitions to impugned statutory terms; it found that the key determinations supporting deportation should be accorded the highest level of deference; and it allowed for exceptional decisions to deport in the face of an established risk of torture. This mixture provides the context for the following discussion.

\section{A. DisCRETION, AND DEFINING "TerRoRism" AND "DANGER TO THE SECURITY OF CANADA"}

Suresh argued that the terms "terrorism" and "danger to the security of Canada" in the Immigration Act are unconstitutionally vague. The Court rejected both arguments. The definition of "terrorism" has long been a concern of refugees and refugee supporters. Refugee communities are composed of persons who have been persecuted for political reasons in their home countries. Many refugees engage in varying degrees of support for opposition movements in their countries. Depending on the breadth given to the term "terrorism," they might easily find themselves included in that ground of inadmissibility. ${ }^{16}$ Justices of the Federal Court have shown a marked reluctance to define "terrorism," virtually adopting an "I'll know it when I see it" approach. ${ }^{17}$ This reluctance echoes the difficulty that legislative drafters at the national and international level have experienced in defining terrorism.

The Supreme Court acknowledged this difficulty, and its origins in the political nature of the exercise. Nevertheless, the Court ventured a non-exhaustive definition of the term. It adopted the definition of "terrorism" given in the International Convention on the Suppression of the Financing of Terrorism:

[An] act intended to cause death or serious bodily injury to a civilian, or to any other person not taking an active part in the hostilities in a situation of armed conflict, when the purpose of such act, by its

11. See discussions of this and other aspects of anti-terrorism measures in Canada's immigration law in S. Aiken, "Manufacturing Terrorists: Refugees. National Security and Canadian Law (Part I)" (2001) 19 Refuge 54, and "(Part 2)" (2001) 19 Refuge 116; and in A. Macklin, "Borderline Security" in The Security of Freedom: Essays on Canada's Anti-Terrorism Bill, R. Daniels, P. Macklem \& K. Roach, eds., (Toronto: University of Toronto Press, 2001) 383.

17 Teitelbaum J. said in Re Suresh (1997), 40 Imm. L.R. (2d) 247 (T.D.), [1997] F.C.J. No. 1537. online: QL (FCJ) at para 26:

I am satisfied that there is no need to define the word "terrorism". When one sees a "terrorist act" one is able to define the word. When one sees a bomb placed in a public market frequented by civilians and the bomb causes death and injury, one is able to see a "terrorist act" or what is referred to as "terrorism".

See also the trial decision in Re Ahani (1998), $42 \mathrm{Imm}$. L.R. (2d) 219 (T.D.), [1998] F.C.J. No. 507, online QL (FCJ) (Denault J.). 
nature or context, is to intimidate a population, or to compel a government or an international organization to do or abstain from doing any act. ${ }^{18}$

The Court rejected what it called a "functional" definition, meaning a listing of specific acts (for example, airplane hijacking, bombing). ${ }^{19}$ It acknowledged in passing that many commentators believe the real difficulty in defining terrorism is the question of selective enforcement, but did not otherwise comment on whether or how this might be justiciable. ${ }^{20}$

The Court recognized a concept of "innocent" membership in a terrorist organization for immigration purposes. This could happen where a person supported a group because of certain activities, without knowledge that it also engaged in terrorist activities. The Court suggested this could be addressed in a submission to the Minister under $\mathbf{s}$. 53(1)(b) of the Immigration Act, going to the last phrase in s. 19(1) of the Immigration Act which exempts persons from being found inadmissible if the Minister believes their presence in Canada is "not detrimental to the national interest." 21 This is intriguing, because a finding of inadmissibility under 19(1) would appear to be a precondition to the consideration of refoulement under 53(1)(b). The Court implies that the "no detriment" issue can be raised before the Minister at any time up to the ultimate decision to deport. ${ }^{22}$

Suresh argued that a person cannot be deemed a danger to security simply by virtue of the finding of inadmissibility on terrorism grounds - essentially that s. 53(1)(b)

It is to be noted that this understanding is similar to the extended definition of "terrorist activity" in the new s. 83.01 of the Criminal Code, introduced by the Anti-Terrorism Act, S.C. 2001, c. 41, following the events of 11 September. The common features are the intention to cause death or serious bodily harm to a civilian, combined with an intention to intimidate the public or compel a government or international organization. The Criminal Code provisions are broader. "Terrorist activity" is said to include acts intended to "cause substantial property damage, whether to public or private property," if such damage is likely to cause death, serious bodily harm, endangering of life, or a public health or safety risk, and acts intended to "cause serious interference with or serious disruption of an essential service, facility or system, whether public or private," all if done for purposes of intimidation. The definition in the Code is narrower in one sense in that the proscribed acts must be committed for a "political, religious or ideological purpose." An interesting question is whether the new Criminal Code provisions will inform the interpretation of "terrorism" in the IRPA. Section 14 of the Regulations to the IRPA state that conviction for a terrorist offence in the Code will satisfy the factual requirements for "terrorism" in the statute.

Suresh, supra note 1 at paras. 97-98.

Ibid. at para. 95:

Even amongst those who agree on the definition of the term, there is considerable disagreement as to whom the term should be attached.... Perhaps the most striking example of the politicized nature of the term is that Nelson Mandela's African National Congress was, during the apartheid era, routinely labelled a terrorist organization, not only by the South African government but by much of the international community.

For a discussion of selective enforcement under similarly open-ended statutory wording in the American context, see G.L. Neuman, "Terrorism, Selective Deportation and the First Amendment after Reno v. $A A D C$ " (2000) 14 Geo. Imm. L.J. 313.

$2 \quad$ Suresh, ibid. at para. 110.

32 lbid. at para. 123, where the Court states that the refugee should be able to address "no detriment" in his or her final submissions in the s. 53(1)(b) process. 
requires a separate finding on that issue. He also maintained that since any terrorist activities engaged in by LTTE occurred outside Canada and were not directed at Canadian interests, he could not be deemed a "danger to the security of Canada."

The Court agreed with Suresh on the first point: s. 53(1)(b) requires the Minister to make a distinct finding that the refugee constitutes a security risk. ${ }^{23}$ However, this does not require a finding of a direct risk to Canadians or Canada. "[A]fter the year 2001," the Court stated, it is no longer tenable to believe that a country's national security is implicated only by terrorism occurring on its own soil. The nature of international terrorism is such that Canada's security can be jeopardized by activities in Canada directed at supporting terrorism in other countries. Still, to find "danger to the security of Canada" requires "proof of a potentially serious threat":

These considerations lead us to conclude that a person constitutes a "danger to the security of Canada" if he or she poses a serious threat to the security of Canada, whether direct or indirect, and bearing in mind the fact that the security of one country is often dependent on the security of other nations. The threat must be "serious", in the sense that it must be grounded on objectively reasonable suspicion based on evidence and in the sense that the threatened harm must be substantial rather than negligible. $^{24}$

This leads to considerable uncertainty about the kind of activity in Canada by a "member of an organization engaged in terrorism" in another part of the world that would constitute a danger to Canada's security. Since the Court viewed Canada's contribution to the international struggle to combat terrorism as a factor that may enhance Canada's security, this determination may depend on how strongly the government is being pressed by other countries, or who the government views as an influential player on the world stage. The Court's insistence that it is not enough to show membership in a terrorist organization, without a separate showing of a security risk, may be most pertinent when an organization's terrorist activity is a thing of the past. The definition of "terrorism" in the Immigration Act extends to former membership in an organization that formerly engaged in terrorism. It may be much more difficult to establish a "serious threat" to Canada's security with respect to a person's membership in a defunct or now law-abiding organization.

The Court made it clear that any uncertainty about whether a refugee is a danger to Canada's security should generally be resolved by the Minister. As noted, the Court described this as a finding of fact to which the judiciary should accord the highest degree of deference. The Court emphasized this point with its second reference to changes in thinking caused by the events of 11 September. The Court quoted with approval the opinion of Lord Hoffman in the House of Lords decision in Rehman:

Ibid. at para 83:

We would not conflate s. 19's reference to membership in a terrorist movement with "danger to the security of Canada." While the two may be related, "danger to the security of Canada", in our view, must mean something more than just "person described in s. 19". 
I wrote this speech some three months before the recent events in New York and Washington. They are a reminder that in matters of national security, the cost of failure can be high. This seems to me to underline the need for the judicial arm of government to respect the decisions of ministers of the Crown on the question of whether support for terrorist activities in a foreign country constitutes a threat to national security. It is not only that the executive has access to special information and expertise in these matters. It is also that such decisions, with serious potential results for the community, require a legitimacy which can be conferred only by entrusting them to persons responsible to the community through the democratic process. If the people are to accept the consequences of such decisions, they must be made by persons whom the people have elected and whom they can remove. ${ }^{25}$

This is a striking assertion. By recognizing a heightened legitimacy for executive decision-making in national security matters, the Court undermines the legitimacy of judicial review. This statement might merely be viewed as the Court further justifying its assertion that the Minister's decision on the "danger to security" issue is reviewable on a standard of patent unreasonability, rather than an indication of an even more deferential standard. There is no suggestion by the Court that this decision is a prerogative power, or a "political question" beyond the reach of judicial review entirely. Nevertheless, and despite describing the decision on danger to the security of Canada as a factual question for which there must be an evidentiary basis, the Court signalled that the executive has considerable leeway in making this decision. ${ }^{26}$

\section{B. DISCRETION IN ADMINISTRATIVE LAW: SURESH AND BAKER}

Canadian administrative law has undergone significant changes in recent years, particularly with respect to substantive review of statutorily delegated decision-making. The principal change has been a move away from asking whether a decision-maker is acting within jurisdiction to an approach that asks which of three standards of review a court should employ: correctness (no deference), patent unreasonability (considerable deference), or reasonableness simpliciter (a middle standard of deference). In recent years, immigration cases have played a significant role in this development. ${ }^{27}$ This may simply reflect the great volume of delegated decision-making generated by the immigration system. It may also reflect the degree to which the Immigration Act relies on broad discretionary authority, including ministerial discretion as a mode of decisionmaking.

The Supreme Court's decision in Suresh turns very much on the Court's development of common-law principles in Baker. The latter case represents both a rethinking of

Ibid. at para. 33, quoting from Secretary of State for the Home Department v. Rehman, [2001] 3 W.L.R. 877 (H.L.) at para. 62 [emphasis added by the S.C.C.].

26. Suresh, ibid. at para. 85:

We also accept that the determination of what constitutes a "danger to the security of Canada" is highly fact-based and political in a general sense. All this suggests a broad and flexible approach to national security and, as discussed above, a deferential standard of judicial review.

:7 See, e.g., Pushpanathan v. Canada (Minister of Citizenship and Immigration), [1998] I S.C.R. 982, and Baker, supra note 4. 
several basic issues in Canadian administrative law, and a rejection of previously settled approaches taken by the Federal Court of Appeal in immigration matters. In Suresh, the somewhat testy dialogue between these Courts continued, resulting in a retrenchment by the Supreme Court.

The facts in Baker were these: Mavis Baker had overstayed a visitor's visa by several years, and therefore had no legal status in Canada. When Citizenship and Immigration moved to deport her, she applied to the Minister under s. 114(2) of the Immigration Act to remain in Canada on humanitarian and compassionate grounds. The Minister's delegate refused the application, and Baker sought judicial review. She argued a number of grounds including breach of procedural justice by being denied an oral hearing, and a substantive failure by the delegate to give due weight to the best interests of her four Canadian-born children. The Federal Court of Appeal applied its established jurisprudence to the effect that humanitarian and compassionate decisions by the Minister give rise to minimal procedural rights, and are reviewable only if the claimant is able to show irrationality or palpable error. ${ }^{28}$

The Supreme Court allowed Baker's appeal, taking the opportunity to expand significantly the scope of review for discretionary decisions in general, and humanitarian and compassionate decisions in the immigration field in particular. Baker was found to have much more than minimal procedural rights, although these did not require that she receive an oral hearing. On the substantive side, the Court achieved a broadened scope for review in two ways. First, L'Heureux-Dubé J. signalled that discretionary decisions should no longer be viewed as conceptually distinct from decisions on issues of law. Judicial review of both should commence with a "pragmatic and functional" analysis directed at determining which of the three standards of review is applicable to the decision in question. Justice L'Heureux-Dube then found that in this exercise of ministerial discretion, the reasonableness simpliciter standard was appropriate. Further, she found the delegate's decision unreasonable because he had failed to give sufficient weight to the best interests of Baker's children. In L'HeureuxDubé J.'s words, the delegate had failed to be sufficiently "alert, alive and sensitive" to those interests. ${ }^{29}$

This drew the criticism of Robertson J.A. in the Federal Court of Appeal decision in Suresh. He questioned whether the Supreme Court could really have intended to make new law by suggesting that in judicial review of ministerial exercises of statutory discretion, the judiciary's role involves reweighing relevant considerations:

What is significant about Baker, supra, is that the Supreme Court did not conclude that the Minister's decision should be set aside on the ground that she failed to take into account a relevant consideration, namely the interests of Mrs. Baker's Canadian-born children. What Baker, supra, establishes is that if "insufficient" weight is given to a relevant consideration then the decision cannot stand. As the interests of the children had been "minimized", the Minister's exercise of her discretion was deemed "unreasonable". Quaere: How does a tribunal or administrative official respond to a direction to give 
more weight to one consideration? How does one determine whether sufficient weight is given to a factor without prejudging or directing the outcome of a decision ${ }^{30}$

Without fully acknowledging it, the Supreme Court in Suresh backed away from the position it had taken in Baker. The Court defended Baker by saying that it had not in fact held that the judiciary should reweigh relevant considerations. Rather, it had merely sought to hold the decision-maker to the Ministry's own guidelines on weighing the factor of children's best interests:

The passages in Baker referring to the "weight" of particular factors (see paras. 68 and 73-75) must be read in this context. It is the Minister who was obliged to give proper weight to the relevant factors and none other. Baker does not authorize courts reviewing decisions on the discretionary end of the spectrum to engage in a new weighing process, but draws on an established line of cases concerning the failure of ministerial delegates to consider and weigh implied limitations and/or patently relevant factors. ${ }^{31}$

The Federal Court of Appeal has taken note of this retreat, and applied it in a case further exploring the role of children's best interests in a parent's deportation. ${ }^{32}$

This discussion is significant for future cases on deportation to a risk of torture. The Supreme Court has confirmed a "constitutional standard," discussed below, which appears to provide strong protection to persons threatened with deportation where a substantial risk of torture exists. However, the factual determination of whether such a risk exists is left to the Minister, and the Supreme Court is clear that the judiciary must grant the highest level of deference to this finding. The middle standard of reasonableness simpliciter does not apply and relevant factors are not to be reweighed. It takes little imagination - nor is it a statement of cynicism - to see that this factual

Suresh v. Canada (M.C.I.), [2000] 2 F.C. 592 (C.A.) at para. 141. Robertson J.A. did not conceal his frustration with the Supreme Court, as further evidenced by this statement at para. 136:

It may well be that the law underwent radical reform with the arrival of Baker, supra. But I am not confident that this is so. If the Supreme Court embarks on fundamental change in the law it usually states as much by expressly overruling its earlier precedents. Be that as it may, Baker cannot be ignored even if one of its critical holdings constitutes obiter dictum.

"Suresh, supra note 1 at para. 37. Robertson J.A.'s reading of Baker seems eminently justified in light of such passages as this, at para. 65:

In my opinion, the approach taken to the children's interests shows that this decision was unreasonable in the sense contemplated in Southam, supra. The officer was completely dismissive of the interests of Ms. Baker's children. As I will outline in detail in the paragraphs that follow, I believe that the failure to give serious weight and consideration to the interests of the children constitutes an unreasonable exercise of the discretion conferred by the section, notwithstanding the important deference that should be given to the decision of the immigration officer.

Suresh is not the only opportunity the Supreme Court has taken to distance itself from the fuller reading of Baker. In his concurring opinion in Mount Sinai Hospital Center v. Quebec (Minister of Health and Social Services), [2001] 2 S.C.R 281 at paras. 55-61, Binnie J. stressed that Baker is consistent with the principle that, almost invariably, exercises of ministerial discretion should be accorded the highest degree of deference by reviewing courts.

32 Legault v. Canada (Minister of Citizenship and Immigration) (2002), 212 D.L.R. (4th) 139, [2002] F.C.J. No. 457, online: QL (FCJ) at paras. 8-12. 
question will be the nub of future deportations. The Minister will be in a much stronger position to base a decision to deport on a finding that the person does not face a substantial risk of torture than to make out a case for "exceptional circumstances" under the constitutional standard. ${ }^{33}$

On the procedural side, however, the Supreme Court in Suresh went further than it had in Baker. This is particularly true with respect to the duty to give reasons. Baker moved the law forward on this question by finding that when an important personal interest is at stake, the duty of fairness requires that an administrative decision be accompanied by reasons. The Supreme Court concluded that this duty had not been breached in Baker, on the basis that the handwritten notes of an immigration officer summarizing the facts and making a recommendation to the decision-making officer constituted reasons for the decision. This was unsatisfying. If one of the main purposes for requiring reasons is to improve the quality of decisions by obliging the decisionmaker to articulate a set of reasons, the purpose is not served by accepting a subordinate's contribution as reasons for decision. ${ }^{34}$ In Suresh, the Supreme Court strengthened the reasons requirement:

The Minister must provide written reasons for her decision. These reasons must articulate and rationally sustain a finding that there are no substantial grounds to believe that the individual who is the subject of a s. 53(1)(b) declaration will be subjected to torture, execution or other cruel or unusual treatment, so long as the person under consideration has raised those arguments. The reasons must also articulate why, subject to privilege or valid legal reasons for not disclosing detailed information, the Minister believes the individual to be a danger to the security of Canada as required by the Act. In addition, the reasons must also emanate from the person making the decision, in this case the Minister. rather than take the form of advice or suggestion, such as the memorandum of Mr. Gautier. ${ }^{35}$

This is part of a significant ongoing development: exercises of ministerial discretion dealing with serious personal interests, whether constitutionally protected or not, are being held to extensive procedural obligations.

Suresh was argued together with Ahani, supra note 6, in which the appellant also raised the risk of torture issue. The Supreme Court dismissed the appeal in Ahani on the basis that the Minister's finding that no substantial risk of torture existed was not patently unreasonable.

3s Baker, supra note 4 at para. 39. In Suresh (F.C.A.), supra note 30 at para. 55, Robertson J.A. was not charitable in describing this aspect of the Supreme Court's decision in Baker:

Counsel for the Minister does not dispute the proposition that written reasons are required but does dispute the argument that the memorandum prepared by Mr. Gauthier does not satisfy this requirement. In my view, there is no merit to the appellant's argument. If, as was held in Baker, supra, the scribbled notes of an immigration officer can be deemed written reasons then so too can the memorandum submitted to the Minister in the present case. detailed reasons by the decision-maker is a requirement of s. 7 of the Charter, rather than of the administrative law duty of fairness. The Court was not clear on that point. 


\section{DISCRETION AND SECTION 7 OF THE CHARTER: SURESH AND BURNS AND RAFAY}

Section 7 is arguably the most complex provision in the Charter, and has been the source of considerable controversy. With respect to complexity, s. 7 is understood to contain both a threshold and a multifaceted set of rights. The threshold is that a claimant must be able to show that impugned government action limits one or more of the interests of life or liberty or security of the person. Supreme Court jurisprudence is now settled that "liberty" and "security of person" are not limited to physical phenomena, but may go to state intrusions in the matters of fundamental personal choice, and psychological integrity. ${ }^{36}$ Section 7 protects the interests of life, liberty or security by guaranteeing that state interference with them must be in accordance with the "principles of fundamental justice." Much of the controversy stems from the Court's jurisprudence which recognizes both a procedural and substantive dimension to fundamental justice.

Complexity is added when the substantive justice branch of s. 7 is applied to an exercise of statutory discretion, rather than to a statute. ${ }^{37}$ That is the case in the Supreme Court's decision in Suresh ${ }^{38}$ Discretion implies a degree of flexibility in possible decision-making outcomes. A breach of substantive justice implies that a certain outcome is unjust, and thus impermissible. In Suresh, the Supreme Court sought to retain the Minister's discretion while structuring it to ensure compliance with s. 7.

To identify precisely the role that s. 7 plays in Suresh, we must consider two matters: (1) how the use of s. 7 in Suresh corresponds to the scheme of threshold, procedural and substantive fundamental justice issues; (2) the nature of the constitutional standard of review which the Supreme Court finds required as a matter of substantive fundamental justice.

\section{ThreShOld ISSUES AND PROCEDURAL AND SUBSTANTIVE JUSTICE}

\section{a. Threshold Issues}

The Court did not find it necessary to dwell on this issue: "It is conceded that 'everyone' includes refugees and that deportation to torture may deprive a refugee of liberty, security and perhaps life." ${ }^{39}$ Is a threat of torture needed to satisfy the

See Blencoe v. British Columbia (Human Rights Commission), [2000] 2 S.C.R. 307.

J.M. Ross, "Applying the Charter to Discretionary Authority" (1991) 29 Alta. L. Rev. 382. Ross uses the terms "facial" and "as applied" constitutional review to apply to challenges to statutory provisions, and to exercises of discretion, respectively. The article explores various implications of Slaight Communications Inc. v. Davidson, [1989] I S.C.R. 1038, in which the Supreme Court first applied the Charter to an exercise of discretion.

The Federal Court of Appeal, by contrast, had largely dealt with the issue as one of facial constitutionality of s. 53(1)(b). The Court of Appeal found that by permitting refoulement to torture, s. 53(1)(b) violated s. 7, but that this was justified under s. I due to the serious consequences to national security of sheltering suspected terrorists.

Suresh, supra note 1 at para. 44. 
threshold test? There would seem to be sufficiently serious personal interests at stake in the deportation of a refugee to the persecuting country for s. 7 to apply. The Court in Singh found that the claim of a risk of persecution raised a security of the person issue. The effect of a decision to deport is the same as a decision to deny refugee status. Since refoulement only relates to a person who has a well-founded fear of persecution, the threat of persecution is more imminent than in the status-determination situation. Indeed, subsequent to Suresh, the Ontario Court of Appeal noted precisely this point: even where a refugee fails to show that he faces a risk of torture, the risk of persecution itself means $\mathbf{s .} 7$ applies to the decision. ${ }^{40}$ This suggests that the risk of torture is a "threshold" issue not for fundamental justice in a procedural sense, but for the substantive branch of the right.

\section{b. Procedural Justice}

The Supreme Court found in Suresh's favour on this basis. It ruled that the Minister breached s. 7 by failing to disclose an internal report to Suresh, thus giving him no opportunity to respond to it. However, the existence of a s. 7 right is of little consequence to these procedural entitlements. The Supreme Court has repeatedly stated that just procedure in administrative law and procedural justice in $\mathrm{s} .7$ are equivalent in terms of their content. More precisely, the Court has not yet found an occasion in which s. 7 applies, and thereby provides an individual with greater procedural protection than would be received as a matter of common law. Nor is Suresh such an occasion. In addressing the alleged procedural breaches in Suresh, the Court begins by saying it is appropriate to apply the common-law test for the content of procedural rights developed in Baker. ${ }^{41}$

To date, the significance of $\mathrm{s}$. 7 to procedural justice is that it provides the constitutional basis for challenging a statutory bar to common law entitlements. That is the role identified for s. 7 by Wilson J. in Singh. There is no statutory bar to disclosure of the internal report to the Minister in refoulement decisions. ${ }^{42}$ Just as in Baker, the statutory provision in question grants authority to the Minister to make a decision, with no reference to procedure.

Ahani v. Canada (A.G.) (2002), 19 Imm. L.R. (3d) 231, [2002] O.J. No. 431, online: QL (OJ) at para. 27. This concerned a final attempt to avoid removal by the same individual whose appeal was heard with Suresh, and was dismissed on 11 January 2002. Here, Ahani sought a ruling that it would be a violation of his 5.7 rights to be removed from Canada before the United Nations Human Rights Committee rendered a decision on his application to that body. A majority (Laskin and Charron JJ.A.) of the Court of Appeal rejected this application, Rosenberg J.A. dissenting. Leave to appeal to the Supreme Court refused, [2002] S.C.C.A. No. 62.

"Suresh, supra note 1 at para. 113: "Insofar as procedural rights are concerned, the common law doctrine summarized in Baker, supra, properly recognizes the ingredients of fundamental justice."

42 The Court acknowledged this with the following infelicitous phrasing in Suresh, supra note 1 at para. 121:

Weighing these factors together with all the circumstances, we are of the opinion that the procedural protections required by $\mathrm{s} .7$ in this case do not extend to the level of requiring the Minister to conduct a full oral hearing or a complete judicial process. However, they requirc more than the procedure required by the Act under s. 53(1)(b) - that is, none - and they require more than Suresh received. 
The only role s. 7 might play in Suresh with respect to process would be in confirming that a constitutional interest is at stake, that is, an interest of the greatest seriousness. Seriousness is one of five factors identified in Baker as relevant to the degree of common-law procedural entitlement. It is worth noting that just as in Baker, and despite the existence of a s. 7 interest, the Supreme Court found that Suresh was not entitled to an oral hearing before the Minister on the s. 53(1)(b) decision. Section 7 , therefore, played no part in Suresh's success on the issue of just process.

\section{c. Substantive Justice}

This is where s. 7 mattered in Suresh. Suresh adds to our understanding of what substantive justice means, and when it is available. On the latter point, it is the risk of torture that Suresh may have faced in Sri Lanka that serves as the "threshold" for substantive justice. "Mere" persecution short of torture would likely be insufficient. The power to refoule represented in s. 53(1)(b) is, the Supreme Court finds, an appropriate expression of the right extended by Article 33(2) of the Refugee Convention to signatory countries: the right to deport refugees posing a security risk. In other words, refoulement is consistent with existing norms of international law; deporting to a substantial risk of torture is inconsistent with those norms. In the Court's analysis, the latter is a significant factor for finding a substantive s. 7 right.

Suresh may point to the existence of two threshold issues within 5. 7: (a) a threshold of "life, liberty or security of the person" - satisfied for refugees by the risk of persecution - which will be sufficient to trigger the procedural branch of fundamental justice; and (b) a higher threshold fulfilled here by exposure to torture in the receiving country, needed to trigger the substantive branch. What is this higher threshold? It might best be understood as the Canadian government's participation in exposing a person to the risk of cruel and unusual punishment in a foreign country.

Much of the constitutional analysis in Suresh tracks the Court's decision in Canada (Minister of Justice) v. Burns and Rafay. ${ }^{43}$ The issue in Burns concerned the Minister's statutory power to extradite a person to a state that might impose the death sentence. The Supreme Court concluded that s. 7 of the Charter applies to this exercise of discretion by the Minister, and as a matter of substantive fundamental justice imposes an obligation on the Minister to refuse to extradite unless the requesting state gives assurances that it will not seek the death penalty. This constitutional rule is, however, subject to unspecified "exceptional circumstances" that would permit extradition to the death penalty.

The Supreme Court stated in Burns that the guarantee in s. 12 of the Charter against cruel or unusual treatment or punishment covers only actions directly taken by a Canadian government. It is not available where the treatment or punishment is administered by foreign authorities. However, s. 7 can be invoked if there is a sufficient 
nexus between Canadian government action and the exposure of persons in Canada to deprivations of life, liberty or security of the person. ${ }^{44}$

The concept of "substantive fundamental justice" has been criticized as lacking a principled basis, and permitting the judiciary to act as roving commissions of inquiry with respect to Parliament's wisdom in proscribing certain conduct. ${ }^{45}$ This criticism seems less cogent when applied to the "cruel and unusual punishment" branch expressed in Burns and Suresh. Section 12 is itself a statement of substantive justice - that is, that certain measures are so abhorrent that the Constitution puts them beyond the reach of the legislatures. The judiciary's role is to identify those measures. In Burns and Suresh, the Court has employed s. 7 to prevent Canadian governments from facilitating the application of cruel and unusual treatment by foreign states to persons subject to Canadian protection. ${ }^{46}$

\section{THE CONSTITUTIONAL STANDARD OF REVIEW}

The effect of both Suresh and Burns is that the statutory discretion in each instance is constitutional, but its exercise is severely circumscribed. Both cases exemplify an approach to fundamental justice that involves balancing state interests against individual interests. ${ }^{47}$ Burns reversed the outcome of the balancing test applied in the earlier extradition to the death penalty case, Kindler v. Canada (Minister of Justice). ${ }^{48}$ There, the majority concluded that extradition without assurances would violate s. 7 only in exceptional circumstances. By reversing this formula, Burns, and Suresh following it, do something interesting. The balancing test becomes both the means of establishing

Suresh, supra note 1 at para. 54:

Rather, the governing principle was a general one - namely, that the guarantee of fundamental justice applies even to deprivations of life, liberty or security effected by actors other than our government, if there is a sufficient causal connection between our government's participation and the deprivation ultimately effected. We reaffirm that principle here. At least where Canada's participation is a necessary precondition for the deprivation and where the deprivation is an entirely foreseeable consequence of Canada's participation, the government does not avoid the guarantee of fundamental justice merely because the deprivation in question would be effected by someone else's hand.

P. Hogg, Constitutional Law of Canada, looseleaf (Toronto: Carswell, 1997) s. 44-10. See also M. Stephens, "Fidelity to Fundamental Justice: An Originalist Construction of Section 7 of the Canadian Charter of Rights and Freedoms" (2001) 13 N.J.C.L. 183.

Hogg notes, however, that the Supreme Court in cases prior to Burns had permitted extradition of persons at risk of receiving sentences in the foreign jurisdiction that had been determined to be cruel and unusual in Canada pursuant to s. 12 (Hogg, ibid. at s. 44-20).

See T.J. Singleton, "The Principles of Fundamental Justice, Societal Interests and Section 1 of the Charter" (1995) 74 Can. Bar Rev. 446, for a review of Supreme Court decisions up to that date which employed the balancing test. Singleton's argument is that balancing interests in s. 7 rather than in $\mathrm{s.} 1$ of the Charter places an inappropriate onus on claimants, and leaves s. 1 with little to do. In Suresh, the Court indeed sees little role for s. 1. In concluding that the constitutional protection against deportation to torture is subject to exceptional circumstances, the Cour states that such circumstances could be identified and analyzed as balancing factors in $\mathrm{s}$. 7, or as factors justifying limits on the Charter right in s. 1, implying that these are equivalent approaches. Suresh, supra note 1 at para. 78. 
a constitutional standard applicable to all cases, and the means of assessing the circumstances in individual cases.

As noted earlier, the decision in Suresh involves a bifurcation of issues which, in the Supreme Court's analysis, comprise the Minister's scope for discretion under s. 53(1)(b) of the Immigration Act. In fact, the discretion comprises three issues, only the first of which is mandated by the statute:

(1) whether the person is a danger to the security of Canada;

(2) whether, if deported, the person faces a substantial risk of torture;

(3) whether, if a substantial risk of torture exists, the person should be deported.

The second question is mandated by s. 7, but only if the person makes out "a prima facie case that there may be a risk of torture upon deportation ... that torture is a real possibility." ${ }^{49}$ The third issue is also mandated by s. 7 as a matter of substantive justice. This is a residual issue which the Court leaves to ministerial discretion. Section 53(1)(b), after all, contemplates that the Minister's finding that the refugee is a security risk is sufficient authority to deport.

This distinguishes Suresh from Burns. In Burns, the Extradition Act and the Extradition Treaty between Canada and the United States empowered the Minister of Justice to decide whether to extradite with or without seeking assurances concerning the death penalty. ${ }^{50}$ In Burns, s. 7 applied to direct how this power should be exercised. In Suresh, s. 7 is, in an important sense, the source of the power (and duty) to balance factors not contemplated in the statute. ${ }^{51}$ The further implication is that it would be unconstitutional for Parliament to expressly exclude consideration of the risk of torture from refoulement decisions.

The first two issues listed above are made subject to a deferential standard of review. The third issue, in the Court's analysis, is subject to what seems appropriate to call a "constitutional standard of review." 52 This standard goes beyond a standard of correctness, in the sense that the Minister is given no objective criteria to apply to the decision. As in Burns, the Court concludes that if the risk of serious foreign harm

Suresh, supra note 1 at para. 127. The decision on whether the prima facie threshold is met might be viewed as a fourth issue in the Minister's exercise of discretion. Presumably it is reviewable on the patent-unreasonability standard.

S.C. 1999, c. 18. Extradition Treaty between Canada and the United States of America, 22 March 1976, Can. T.S. 1976 No. 3.

s1 The IRPA now makes express reference to the risk of torture in its non-refoulement provision. See IRPA, supra note $5, \mathrm{~s} .115$.

52 Stephens, supra note 45 , refers to a different "constitutional standard" with respect to fundamental justice under s. 7: "conduct that would shock the Canadian conscience," discussed by La Forest J. in the extradition context - see Canada v. Schmidt, [1987] I S.C.R. 500, and Kindler, supra note 48. In Burns at paras. 60-69, the Court sought to de-emphasize this phrase, apparently concerned that it implied too large a role for public opinion. In Suresh, the Court refers to the phrase as meaning what is "fundamentally unacceptable" in Canadian law, to be identified "[w]ithout resorting to opinion polls, which may vary with the mood of the moment" (Suresh, supra note 1 at para. 49 ). 
exists, the Minister cannot as a matter of substantive fundamental justice remove the person from Canada, unless there are "exceptional circumstances." Those circumstances are not specified, and must therefore remain within the judiciary's guardianship. It seems certain that a decision by the Minister to deport in the face of a substantial risk of torture would lead to a review application seeking judicial direction as to whether the circumstances are so exceptional as to support the decision.

In Burns, the Court explicitly refused to speculate on what might constitute exceptional circumstances. ${ }^{53}$ The Supreme Court was more forthcoming in Suresh. This reflects what the Court acknowledged to be a difference between a risk of torture and a risk of the death penalty: the former is significantly more difficult to ascertain. ${ }^{54}$ Whereas the possibility of the death penalty can generally be identified by scanning a foreign state's statute books, torture rarely occurs as a matter of state policy. It may even occur against the wishes or orders of the highest government officials, making any "assurances" they give (as indeed the government of Sri Lanka had given the Minister in Suresh) less than reliable. In this, as in the difference between the physical consequences of torture and capital punishment, the former is more a matter of degree.

In several places in Suresh, the Court alludes to matters of degree that may be circumstances relevant to the Minister's discretion. ${ }^{55}$ There is, however, a difference between relevant circumstances and exceptional circumstances. The former speak to a balancing test, in which the object is to identify the predominant side of a question. The latter speak to circumstances that trump the balancing of relevant factors. In Suresh, the Court is no more willing to speculate on what the judiciary would find "exceptional" than it was in Burns. ${ }^{56}$

\section{Summary: The Role Played by Section 7 of the ChaRTER IN SURESH}

In Suresh, s. 7 of the Charter appears to require each of the following as matters of substantive justice:

Burns, supra note 43 at para. 65 :

Our analysis will lead to the conclusion that in the absence of exceptional circumstances, which we refrain from trying to anticipate, assurances in death penalty cases are always constitutionally required.

Suresh, supra note 1 at paras. 124-25.

ss For example, at para. 77, the Court quotes Lord Hoffman in Rehman, supra note 25 at para. 16: It is a question of evaluation and judgment, in which it is necessary to take into account not only the degree of probability of prejudice to national security but also the importance of the security interest at stake and the serious consequences of deportation for the deportee.

Note also the Court's reference to any limit on Suresh's procedural rights not being justifiable under s. 1 of the Charter: "Nor do the alleged fundraising activities of Suresh rise to the level of exceptional conditions contemplated by Lamer J. in Re B.C. Motor Vehicle Act, supra" (Suresh, supra note 1 at para. 128).

We may predict that [the balance] will rarely be struck in favour of expulsion where there is a serious risk of torture. However, as the matter is one of balance, precise prediction is elusive. The ambit of an exceptional discretion to deport to torture, if any, must await future cases [emphasis added]. 
(1) if an individual facing refoulement makes out a prima facie case of a risk of torture, meeting a threshold for substantive justice, the Minister must consider whether as a factual matter this is the case;

(2) a statutory scheme that barred consideration of the risk of torture would breach s. 7 and not likely be saved under s. $1 ;^{57}$

(3) if it is determined that a substantial risk of torture exists, a new issue for the exercise of discretion arises: whether or not to deport the person concerned;

(4) this last exercise of discretion is reviewable on a constitutional standard that bars deportation, other than in exceptional circumstances.

In the Supreme Court's hands, $s .7$ both creates a series of issues which do not appear in the statute for decision by the Minister, and places a serious substantive limit on the ultimate exercise of discretion by the Minister.

\section{DISCRETIONARY RELIEF AND THE IMMIGRATION AND REFUGEE PROTECTION ACT: SURESH AND CHIARELLI}

This section addresses the issue of discretion in a somewhat different way. The question in Suresh was, in one sense, whether Canadian administrative and constitutional law places limits on a discretionary power that might result in the exposure of an individual to serious harm. As in Baker, however, discretion may be the source of relief for individuals otherwise faced with the harsh consequences of legal rules. The ensuing discussion looks at possible implications of Suresh for the elimination of a discretionary appeal recourse of this kind effected in Canada's new immigration statute.

\section{SECTION 64(1) OF THE IMMGGRTION AND REFUGEE PROTECTION ACT}

Six weeks before the Court rendered its decision in Suresh, Parliament passed the $I R P A$. Although federal officials allowed the impression to exist that IRPA formed part of a rapid response to the events of 11 September, the legislation passed unchanged from the version of Bill C-11 that had been before Parliament since July 2001. One significant change effected by the IRPA is the elimination of a statutory right of appeal from a deportation order for certain permanent residents.

Section 64 of the IRPA reads:

(1) No appeal may be made to the Immigration Appeal Division by a foreign national or their sponsor or by a permanent resident if the foreign national or permanent resident has been found to be inadmissible on grounds of security, violating human or international rights, serious criminality or organized criminality.

(2) For the purpose of subsection (1), serious criminality must be with respect to a crime that was punished in Canada by a term of imprisonment of at least two years.

57 The one possibility for s. 1 justification might be the existence of a national emergency. See Reference re Motor Vehicle Act (British Columbia), s. 94(2), [1985] 2 S.C.R. 486. 
The nature of the appeal to the IAD was discussed by the Supreme Court in a decision released with Suresh on 11 January 2002, Chieu v. Canada (Minister of Citizenship and Immigration). The Court's discussion provides a helpful context for understanding the significance of s. 64(1).

\section{Chieu: An "Ordinary" Deportation}

All non-citizens are subject to deportation from Canada. This includes Convention refugees like Suresh, persons with no legal status in Canada like Mavis Baker, and permanent residents like Huor Chieu. ${ }^{58}$ Chieu was found inadmissible on the basis of misrepresentation: in order to be eligible for family sponsorship as the dependent son of his parents, he had claimed he was single when in fact he was married and had a child. This misrepresentation, as is not infrequently the case, was discovered when Chieu later applied to sponsor his wife and child to come to Canada.

A member of the Adjudication Division of the Immigration and Refugee Board confirmed these facts and issued a removal order against Chieu. Chieu then exercised his statutory right of appeal to the IAD. The grounds for appeal are set out in s. 70(1) of the Immigration Act:

(a) on any ground of appeal that involves a question of law or fact, or mixed law and fact; and

(b) on the ground that, having regard to all the circumstances of the case, the person should not be removed from Canada.

Most deportation appeals rely solely on the second ground, known as the "discretionary" jurisdiction of the IAD. It permits the IAD to relieve a permanent resident against whom a lawful deportation order has been made from having the order executed, if the circumstances of his or her life suggest this is appropriate. This is usually done by issuing a stay of execution of the order for a fixed period of time, generally between three and five years, on certain terms and conditions. In essence, the individual is given a second chance to remain in Canada. If the "probationary" terms are met, then at the conclusion of the fixed period the deportation order will be quashed. If the terms are breached, the Minister can apply immediately for a lifting of the stay.

Parliament conferred this broad discretionary power on an independent administrative tribunal, the Immigration Appeal Board (forerunner of the IAD), in $1967,{ }^{59}$ in recognition of the fact that permanent residents facing possible deportation represent a vast range of individual circumstances. Many came to Canada with their parents as young children; they and many others may have lived most of their lives in Canada, and have established lives in this country, with their own families. The appeal allows

The IRPA introduces a new term, "foreign nationals," which applies to all persons who are neither citizens nor permanent residents. See IRPA, supra note 5 at s. 2(1).

54 lacobucci J. for the Court in Chieu reviewed the history of this discretionary appeal jurisdiction at paras. 33-39, where he cites N. Kelley \& M. Trebilcock. The Making of the Mosaic: A History of Canadian Immigration Policy (Toronto: University of Toronto Press, 1998). 
these kind of circumstances to be examined in detail. It became especially important after 1977, when Canada removed the concept of "domicile" from its immigration law, which had provided permanent residents significant protection from being deported once they had lived in Canada for five years.

In a 1985 decision, Ribic v. Canada (Minister of Employment and Immigration), an IAB panel set out six relevant factors for the exercise of its discretionary jurisdiction. The so-called Ribic factors were thereafter understood by the Board and the courts as appropriately governing the discretion. They are: ${ }^{.0}$

(1) seriousness of the criminal offence (if applicable), or breach of the Immigration Act;

(2) the possibility of rehabilitation or risk of re-offence;

(3) length of time resided in Canada, and degree of establishment in Canada;

(4) family and community support in Canada;

(5) dislocation to family members resulting from the person's removal;

(6) the degree of hardship the person would experience in the receiving country.

At his IAD appeal hearing, Chieu presented evidence going to several of these factors. On the sixth factor, he said that he would suffer hardship if deported to Cambodia, the country of his nationality. Although born in Cambodia of Vietnamese parents, Chieu had not lived there since his family returned to Vietnam when he was a young child. He had no family or other connections in Cambodia. The IAD, however, felt bound by Federal Court of Appeal precedent ${ }^{61}$ to decline to consider the factor of hardship in the foreign country. The Federal Court, both Trial Division and the Court of Appeal, affirmed this decision.

In a judgment written by Iacobucci $J$., the Supreme Court unanimously allowed Chieu's appeal and remitted the matter to the IAD, mandating that foreign hardship be taken into consideration. The Court rejected the main argument which had animated the Federal Court - that it is premature for the IAD to consider foreign hardship since the Minister of Immigration only decides on the country to which a person will be removed after the person's appeal to the IAD is dismissed. The Supreme Court disagreed. It found that the ordinary meaning of the phrase "all the circumstances of the case" would include foreign hardship, and that no policy reasons suggested otherwise.

The Court addressed advantages in having the foreign hardship factor dealt with by an administrative tribunal. In rejecting the government's contention that it is more efficient for the issue of foreign hardship to be dealt with under a s. 114(2) humanitarian and compassionate application to the Minister, Iacobucci J. cited the problems identified by the Court in ministerial exercises of discretion:

To summarize. the scheme of the Act reveals that an appeal to the I.A.D. under s. 70(1)(b) is the most appropriate place for a permanent resident facing removal from Canada to have foreign hardship taken

[1985] I.A.B.D. No. 4, online: QL (IADB).

(1) Hoang v. Canada (Minister of Employment and Immigration) (1990), 13 Imm. L.R. (2d) 35. 
into account. A harmonious reading of the scheme of the Act reveals that all relevant considerations should be considered by the I.A.D. whenever possible. It is only when it is not possible for the I.A.D. to consider potential foreign hardship that other provisions of the Act need be resorted to. These alternative provisions are not as robust as a hearing before the I.A.D. The judicial review of a s. 52 decision provides only narrow grounds for review, and an application to the Minister under s. 114(2) is essentially a plea to the executive branch for special consideration which is not even explicitly envisioned by the Act...

While the Minister's decisions under ss. 52 and 114(2) may well accord with the requirements of natural justice in most cases, I am concerned that this will not always be the case. Baker, supra, is one example of an instance where the Minister's decision was procedurally deficient. It fell to this Court to clarify that the principles of natural justice guarantee certain rights to individuals who make a 5 . 114(2) application, including a right to make written submissions to the Minister's delegate who actually makes the decision, a right to receive brief reasons for the decision, and a right to an unbiased decision maker. ${ }^{62}$

\section{Constitutional Status of Section 64(1)}

Section 64(1) denies automatically the right of appeal to the IAD for persons found inadmissible for certain serious grounds, including a criminal conviction for which a sentence of two years' imprisonment is imposed. In doing so, the provision actually eliminates two exercises of discretion. The first is the IAD's discretionary jurisdiction. Second, s. 64(1) makes it unnecessary for the Minister to issue a "danger opinion" with respect to the individual in question. Danger opinions came into the Immigration Act in $1995 .{ }^{63}$ They too represented an attempt by Parliament to limit recourse to the IAD. The Minister could oust the IAD's appeal jurisdiction for persons found inadmissible for serious grounds, including criminal conviction for an offence with a potential sentence of ten years' imprisonment or more, by issuing an opinion that the person constituted a danger to the public in Canada. ${ }^{64}$ This exercise of discretion was perceived to be an expeditious means of deporting serious criminal offenders. Through judicial review, the procedural obligations on the Minister expanded. This accelerated after the Supreme Court's decision in Baker, which quickly came to be applied by the

62 Chieu, supra note 6 at paras. 64 and 70 .

6.) S.C. 1995 , c. 15.

a Section 70(5) of the Immigration Act:

No appeal may be made to the Appeal Division by a person described in subsection (1) or paragraph (2)(a) or (b) against whom a deportation order or conditional deportation order is made where the Minister is of the opinion that the person constitutes a danger to the public in Canada and the person has been determined by an adjudicator to be

(a) a member of an inadmissible class described in paragraph $19(1)(c),(c .1),(c .2)$ or $(d)$;

(b) a person described in paragraph $27(1)(a .1)$; or

(c) a person described in paragraph $27(1)(d)$ who has been convicted of an offence under any Act of Parliament for which a term of imprisonment of ten years or more may be imposed [emphasis added]. 
Federal Court Trial Division to s. 70(5) decisions. ${ }^{65}$ It seems likely that this development, together with public pressure for faster removal of criminal offenders, prompted the move to automatic deportation without appeal or the need to show dangerousness.

Refugees have the benefit of the right of non-refoulement. Permanent residents have no such protection at international law, and those who meet the criteria in s. 64(1) are deportable on being found inadmissible, regardless of whether they pose a danger to Canadians or to national security.

Concerns have been expressed about this erosion of the rights of permanent residents, including what it means for criminal sentencing. ${ }^{66}$ The Immigration Section of the Canadian Bar Association submitted, in a response to Bill C-11, that s. 64(1) may well be unconstitutional. ${ }^{67}$ Does the decision in Suresh strengthen this argument?

At first glance, that seems unlikely. Section 64(1) is drafted in the spirit of the Supreme Court's decision in Chiarelli v. Canada (Minister of Employment and Immigration).$^{68}$ Justice Sopinka for the Court ruled that the security certificate process did not violate principles of fundamental justice in s. 7 of the Charter. He found that it is a basic tenet of Canadian immigration law that non-citizens do not have an unqualified right to remain in Canada. This leaves Parliament free to set the conditions under which permanent residents may continue to live in this country, so long as the conditions are not arbitrary. ${ }^{69}$ The decision in Chiarelli implies that Parliament is virtually unconstrained by $\mathbf{s} .7$ in designing the procedural and substantive rules for deporting permanent residents.

The Court rejected the argument that denying a permanent resident an appeal going to "all the circumstances of the case" violates principles of fundamental justice. At most, Sopinka J. said, those principles might require a "true appeal" of the

See, e.g., Bhagwandass v. Canada (Minister of Citizenship and Immigration), [2000] I F.C. 619 (T.D.), affd [2001] 3 F.C. 3 (C.A.). This decision overturned the Court of Appeal's pre-Baker judgment in Williams v. Canada (Minister of Citizenship and Immigration), [1997] 2 F.C. 646, which had found that danger opinions called for minimal procedural protections. In Bhagwandass, the Federal Court required disclosure of the Minister's file.

M. Drukarsh, "Immigration Law: Proposed Changes to Replace Discretion with Compulsory Exile" (2000) 21:2 Ontario Criminal Lawyers' Association Newsletter 42.

"In our opinion, the denial of meaningful review of circumstances of permanent residents facing deportation will not be justified under the Charter of Rights, and is inconsistent with Canada's obligations under ... the International Covenant on Civil and Political Rights." Letter to all Members of Parliament from Michael A. Greene, Chair, National Citizenship \& Immigration Law Section, Canadian Bar Association (2 March 2001). Attached as "Correspondence" to "Bill C-11 Immigration and Refugee Protection Act: Issue Papers and Correspondence" (May 2001) National Citizenship \& Immigration Law Section. See discussion in Issue Paper 9, "Appeals of Removal Orders by Permanent Residents and Protected Persons." [1992] 1 S.C.R. 711.

(1) Sopinka J. actually described permanent-resident status as "conditional entry," a remarkably restrictive characterization; ibid. at 736 . 
inadmissibility finding, limited to issues of law and fact. ${ }^{70}$ Is judicial review of an inadmissibility finding a "true appeal"? This is the only recourse provided in the IRPA for a person subject to s. 64(1). Given that review is available only with leave of the Federal Court Trial Division, and that deference is shown to findings of fact, it could be argued that this falls short of the appeal right contemplated in Chiarelli. ${ }^{71}$

Suresh and Chiarelli appear to operate on different jurisprudential tracks dealing with s. 7 and immigration. The former, in the tradition of Singh, operates on the "immigration as protection" track. It locates constitutional rights for persons in Canada in the threats they face in foreign countries. Chiarelli could be said to operate on an "immigration as privilege" track - that is, where the immigrant's attachment to Canada is unrelated to a need for protection, then Canada owes no constitutional duty of fundamental justice to the immigrant. In other words, s. 7 is available to protect persons from serious harm perpetrated by foreign governments, but not from the personal hardships caused by deportation.

However, this overstates the distinction between the cases. First, the Court in Chiarelli expressly declined to decide whether the act of deportation itself meets the s. 7 threshold of limiting rights of life, liberty or security of the person. This question remains unanswered. ${ }^{72}$ Further, it must be remembered that in Suresh, just as in Chiarelli, the impugned statutory provisions of the Immigration Act were upheld as constitutional. The Court found it was the application of those provisions to individual situations involving a risk of torture that could potentially violate s. 7. Might this same kind of "as applied" analysis be available in instances of deportation pursuant to $\mathrm{s}$. $64(1)$ ?

Certainly this is true in circumstances which involve deportation to a substantial risk of torture. The Court implies in Suresh that the constitutional standard of review is not limited to refugees, but is a general principle that applies to anyone subject to removal

Ibid. at $741-42$ :

It can thus be seen that there has never been a universally available right of appeal from a deportation order on "all the circumstances of the case". Such an appeal has historically been a purely discretionary matter. Although it has been added as a statutory ground of appeal, the executive has always retained the power to prevent an appeal from being allowed on that ground in cases involving serious security interests.

If any right of appeal from the deportation order in s. 32(2) is necessary in order to comply with principles of fundamental justice, a "true" appeal which enables the decision of the first instance to be questioned on factual and legal grounds clearly satisfies such a requirement. The absence of an appeal on wider grounds than those on which the initial decision was based does not violate s. 7 .

"IRPA, supra note 5 at s. 72. In Canada, issues of law and fact are straightforward, and can be satisfied by entering proof of the conviction and sentence. The issues with respect to other inadmissibility grounds, such as terrorism, may often be complex.

72 The Court perhaps gives a hint of the view it might take in the future when it says, in Suresh, supra note 1 at para. 118:

The greater the effect on the life of the individual by the decision, the greater the need for procedural protections to meet the common law duty of faimess and the requirements of fundamental justice under s. 7 of the Charter. Deportation from Canada engages serious personal, financial and emotional consequences. 
from Canada. ${ }^{73}$ In the companion case to Chieu, Al Sagban, the Court went so far as to state that if Al Sagban had been able to show that he faced a substantial risk of torture on being returned to Iran, he would not be deportable. ${ }^{74}$

That the kind of constitutional protection extended in Suresh will be available to persons subject to s. 64(1) who face a serious risk of harm in the receiving country is made even more evident by the fact that Parliament has incorporated a "pre-removal risk assessment" into the IRPA. ${ }^{75}$ This permits a person facing deportation to apply to the Minister for protection on grounds set out in s. 97(1) of the IRPA:

(a) ... a danger, believed on substantial grounds to exist, of torture within the meaning of Article 1 of the Convention Against Torture; or

(b) to a risk to their life or to a risk of cruel and unusual treatment or punishment if

(i) the person is unable or, because of that risk, unwilling to avail themself of the protection of that country,

(ii) the risk would be faced by the person in every part of that country and is not faced generally by other individuals in or from that country,

(iii) the risk is not inherent or incidental to lawful sanctions, unless imposed in disregard of accepted international standards, and

(iv) the risk is not caused by the inability of that country to provide adequate health or medical care.

When engaging in a pre-removal risk assessment, the Minister should be subject to the procedural and substantive requirements set out in Suresh.

The more challenging question is whether circumstances other than the threat of torture in a foreign country might come to be viewed as implicating rights of life, liberty or security of the person, such that they must, by mandate of s. 7, be subject to a balancing exercise before deportation can be effected. Consider the facts in Romans v. Canada (Minister of Citizenship and Immigration). ${ }^{76}$ There, a 35 year-old permanent resident from Jamaica was ordered deported for criminality, based on several convictions. He appealed to the discretionary jurisdiction of the IAD. The evidence showed he had come to Canada at the age of two. He developed paranoid schizophrenia in his late teens, and that illness together with substance abuse seemed to be the major contributors to his criminal conduct. All his family, which remained supportive, lived in Canada. If deported to Jamaica, he would likely receive poor medical assistance and his condition would only worsen. The IAD nevertheless dismissed the appeal,

Ibid. at para. 54.

Al Sagban, supra note 6 at para. 13. It is worth noting that $A l$ Sagban makes it clear that the foreign hardship factor which the Court finds within the IAD's jurisdiction goes beyond highly individualized concerns (e.g., no family in the country, no familiarity with its language and culture) to issues of persecution and torture.

IRPA, supra note 5 at ss. 112-15. A pre-removal assessment in different terms was previously set out in the Immigration Regulations. 1978, SOR/78-172. See definition in those Regulations of "member of the post-determination refugee claimants in Canada" class.

(2001), 14 Imm. L.R. (3d) 215, [2001] F.C.J. No. 740 (T.D.), online: QL (FCJ). 
considering that the danger the appellant posed to the public in Canada outweighed the other factors.

Counsel for Romans argued that s. 7 applied because deportation interfered with his liberty and security of person. Counsel further argued that in these circumstances, substantive fundamental justice required that the appellant not be deported. Justice Dawson agreed that s. 7 applied, but found that Chiarelli precluded viewing the appellant's deportation as a violation of the principles of fundamental justice. Her decision predated Burns. She noted that the possibility of a substantive requirement to decline to extradite to the death penalty, discussed by the Supreme Court in Kindler, could not easily be analogized to the deportation context.

The Federal Court of Appeal affirmed this decision. ${ }^{77}$ It commented:

We are satisfied that, in doing so, [the lAD] did a balancing of competing interests as mandated, albeit in different circumstances, by the Supreme Court of Canada in United Siates v. Burns, [2001] 1 S.C.R. 283 and could, on the evidence before it, reach the conclusion that the deportation of the appellant, in the circumstances of this case, was in accordance with the principles of fundamental justice. ${ }^{78}$

Section 64(1), of course, purports to eliminate the "balancing of competing interests" for certain permanent residents.

It seems conceivable that, given circumstances which demonstrated a serious harm caused by deportation from Canada, the statutory denial of the opportunity to balance these factors against the state's interest in deportation might be viewed as a violation of s. $7 .{ }^{79}$ One such harm might be the deportation of persons with mental illness to situations where there is a substantial risk of deterioration, if not collapse, of their health and well-being. After all, the balancing of factors in a case like Romans reveals a state interest in using the deportation process to "solve" what should more sensibly be seen as a Canadian health problem. Another such harm might involve serious prejudice to the best interests of children caused by a parent's removal. The first issue is not yet supported by the kind of international consensus which exists with respect to torture; the second issue is an emerging norm, represented in the Convention on the Rights of the Child. ${ }^{80}$

(2001), 17 Imm. L.R. (3d) 34, [2001] F.C.J. No. 1416 (C.A.), online: QL (FCJ). Leave to appeal to the Supreme Court refused, [2001] S.C.C.A. No. 471, online: QL (SCCA).

lbid. at para. 4.

79 Of course, a discretionary consideration of such factors may be available through the Minister's humanitarian and compassionate jurisdiction, formerly under s. 114(2) of the Immigration Act, and now s. 25 of the IRPA. The Minister's position in Chieu, which relied heavily on submitting that the factor of hardship could be considered in such applications, implies this is an available and appropriate recourse. Given the significant procedural protections that the Supreme Court has found required of this form of decision-making in Baker and Suresh, it may not be long before the pendulum swings back to seeing the desirability of placing an expanded discretionary jurisdiction with an administrative tribunal. 
The analysis of how s. 7 plays out in Suresh suggests that, as such norms achieve recognition as threshold issues of substantive justice, a hierarchy of constitutional responses is available: first, statutory exclusion of the issue from consideration may be invalid; ${ }^{81}$ second, a discretionary authority allowing the issue to be considered may be required; third, the substantive exercise of the discretion may be subject to a constitutional standard; and fourth, at a point beyond Suresh, substantive justice may deny the possibility of breaching the norm.

\section{CONCLUSION}

The Supreme Court of Canada's judgment in Suresh could be viewed as an example of the Court's searching for a political answer to a hard case. Faced with weighing Canada's response to the threat of terrorism against its commitment to combat the scourge of torture in the charged atmosphere created by 11 September, the Court found a middle position. It made a strong statement on the need to protect potential victims of torture, while allowing for the possibility of exposing persons involved in terrorism to the risk of torture in exceptional circumstances.

An outright prohibition on deportation to torture would seem a stronger human-rights statement. This is what the appellant had sought by challenging s. 53(1)(b) of the Immigration Act. Proposed remedies included striking the provision down and placing the onus on Parliament to craft an exception dealing with a risk of torture, or reading such an exception into the provision. Either would place the Supreme Court in an uncomfortable position at an uncomfortable time. The Court may well have achieved much the same thing without having to make any declaration of unconstitutionality. It accomplished this by approaching the issue as concerning an exercise of discretion, rather than of statutory mandate. One of the virtues of discretionary decision-making is thought to be its flexibility. In Suresh, the Court availed itself of this flexibility, and in doing so found its own shelter.

The fact that this may have been the Court's reasoning does not detract from the richness of its discussion in Suresh. The judgment provides fertile ground for consideration of a number of questions about the relationship between the executive and the judiciary, and about recent developments in Canadian constitutional and administrative law. What it may mean for the country's newly reworked immigration law - arriving as it does at a moment of heightened international security concerns must await future events. But the renewed commitment to Canadian law as a source of protection for those threatened with harm abroad is a promising place to begin.

*I Note the express exclusion, in s. 97(1)(b)(iv) of the IRPA, of a discretion going to the absence of appropriate medical care in a foreign country as a source of cruel and unusual treatment, and quaere its status under $\mathrm{s.} 7$ of the Charter. 